This is the accepted manuscript of the article, which has been published in Weiss, Christina (ed) Constructive Semantics : Meaning in Between Phenomenology and Constructivism, 123-133. https://doi.org/10.1007/978-3-030-21313-8_5

To appear in Weiss, Christina (ed.). Constructive Semantics - M eaning in Between Phenomenology and Constructivism. Logic, Epistemology and the Unity of Science Series. Springer. Please, cite the published version.

\title{
Constitution and construction
}

Mirja Hartimo

University of Jyväskylä

Keywords: Phenomenology, logical construction, constitution of abstract objects, Husserl

In the recent literature on Husserl's philosophy of mathematics the notions of constitution and construction have been assimilated (Da Silva 2017, van Atten 2017). The aim of this paper is to explain why this is problematic. The crux of the argument is that while construction in Husserl's texts takes place in the natural mathematical attitude, constitution of the mathematical reality is revealed in the transcendental phenomenological attitude. Equating the two notions leads to misreading either Husserl's notion of the transcendental attitude (cf. da Silva 2017; Hartimo 2017) or else to a failure to appreciate the role of the natural attitude in Husserl's approach (cf. van Atten 2017; Hartimo 2016). Since both mathematics and phenomenology are eidetic sciences, i.e., they are both about ideal structures, the difference between the two is perhaps difficult to grasp. However, a closer look shows them to be fundamentally different, both in method and in subject matter. The most fundamental difference between construction and constitution is in the attitude: in Husserl's approach, construction takes place in natural mathematical attitude and constitution is something studied in transcendental phenomenological attitude.

To explain all this, I will start by discussing Husserl's idea of correlation, i.e., the idea how what is experienced as objective and the manners of givenness of the objective are correlated. The purpose of this discussion is to remind the reader of the important differences between the two attitudes in general. I will then explain the differences between construction and constitution in mathematics by means of these two attitudes. I will then move on to discuss Husserl's notion of "construction" in more detail. 
Husserl uses the term "construction" in (at least) two senses. In a wider sense, construction refers to any manner of building mathematical theories. In its narrower sense the term refers more specifically to "logical construction," that is an activity carried out in "theory of judgment". Considering the differences in the constitution of the "logically constructed" vs. the (mathematically) "constructed" reveals the two kinds of construction to be guided by different kinds of evidence. I will end the paper by considering the roles of logical construction and constitution in Husserl's philosophy of mathematics more generally.

\section{Correlation}

Phenomenology is a study of the correlation between the world and its subjective manners of givenness. In the Crisis Husserl writes that

"[t]he first breakthrough of this universal a priori of correlation between experienced object and manners of givenness (which occurred during [the] work on my Logical Investigations around 1898) affected me so deeply that my whole subsequent life-work has been dominated by the task of systematically elaborating on this a priori of correlation" (Crisis 166n). ${ }^{1}$

And indeed, his work since 1898 can be regarded as an elaboration of the correlation, that is, how, thanks to my subjective achievements, the objective world is given to me. The correlation is between the world and our activities of structuring it. According to Ideas I, the objective end of the correlation is the world as encountered in the so-called natural attitude. The natural attitude is the attitude in which we find ourselves "naturally", within our experiences, in medias res, as Quine would have it - no attempt at looking at the world from the outside is involved in it. The world of the natural attitude is the way in which I take the world to be there (described from the first-person perspective): I take it as spreading endlessly in space and time. I can sense it in various ways and I can be moved by it in various ways. There are corporeal things and other people and I take them to be there even if I am not looking. Some things I see indistinctly and unclearly. The immediate environment is vested with expectations of what could happen. Furthermore, the "world is not there for me as a mere world of facts and affairs, but, with the same immediacy, as a world of values, a world of goods, a practical world" (Ideas I, §27). The world of natural attitude has more specified worlds that result from the more specified attitudes nested in it. Thus, for example, the world of arithmetical attitude is there for me as long as I am in the

\footnotetext{
${ }^{1}$ «Der erste Durchbruch dieses universalen Korrelationsapriori von Erfahrungsgegenstand und Gegebenheitsweisen (während der Ausarbeitung meiner 'Logischen Untersuchungen' ungefähr im Jahre 1898) ershütterte mich so tief, daß seitdem meine gesamte Lebensarbeit von dieser Aufgabe einer systematischen Ausarbeitung dieses Korrelationsapriori beherrscht war.» (Krisis, 169n).
} 
arithmetical attitude, absorbed in proving something, while the natural world in the usual sense is there for me continuously (Ideas I, §28). Furthermore, I do not think of myself to be the only one in the world. I understand other people to be similar subjects of experiences as what I am (Ideas I, §29). I also think that the world is actually there. I do not doubt its existence, nor do I doubt other humans' existence. Because of this Husserl characterizes the natural attitude by a "Generalthesis", general positing of existence.

\section{Constitution}

The description of the natural world sets up the task for transcendental phenomenology, the task of describing how the world is given, how we constitute it. The constitution refers to the achievements of our consciousness due to which we experience the world as described in the natural attitude. In the natural attitude we are unaware of the way in which the world is constituted. In order to shift our focus from our natural interests to the nature of constitution, 'phenomenological reduction' has to be effected. This means that the general thesis, the positing of the existence of the world is bracketed or interrupted. Yet, in bracketing the naïve positing of the world's existence, the phenomenologist does not lose any of the predicates or determinations that belong to the world. The entire world remains continually there, with all its determinations, available for the phenomenologist to start examining it (Ideas I, §32). In the phenomenological reduction then,

"we put all those positings 'out of action,' we do not 'participate in them;' we direct our seizing and theoretical inquiring regard to pure consciousness in its own absolute being. That, then, is what is left as the sought-for 'phenomenological residuum,' though we have 'excluded' the whole world with all physical things, living beings, and humans ourselves included. Strictly speaking, we have not lost anything but rather have gained the whole of absolute being which, rightly understood, contains within itself, 'constitutes' within itself, all worldly transcendencies" $(\S 50,113)^{2}$

2 “... setzen wir all diese Thesen, die aktuellen und im voraus die potenziellen 'außer Aktion', wir machen sie nicht mit; unseren erfassenden und theoretisch forschenden Blick richten wir auf das reine Bewubtsein in seinem absoluten Eigensein. Also das ist es, was als das gesuchte 'phänomenologische Residuum' übrig bleibt, übrig, obwohl wir die ganze Welt mit allen Dingen, Lebewesen, M enschen, uns selbst inbegriffen 'ausgeschaltet' oder besser eingeklammert haben. Wir haben eigentlich nichts verloren, aber das gesamte absolute Sein gewonnen, das, recht verstanden, alle weltlichen Transzendenzen als intentionales Korroelat der ideell zu verwirklichenden und einstimmig fortzuführenden Akte habitueller Geltung in sich birgt, sie in sich 'konstitutiert'." (Ideen I, 118119). 
In other words, the reduction changes our focus from theorems and proofs to examine the activity of constructing, to pure consciousness. In pure consciousness all the worldly transcendences are, so to say, constituted. As is well known, Husserl's best-known examples are about the constitution of the objectively existing object of perception, such as a tree. We constitute the perceived object as a unity even though it is given in data that is in flux: in adumbrations with an external and internal horizon, i.e., anticipations of what else is given with the thing and what the thing will look like on the other side, etc. In Ideas I Husserl distinguishes between the physical thing and the noema that is constituted by us:

"The tree simpliciter, the physical thing belonging to Nature, is anything but (nichts weniger als) this perceived tree as perceived which, as perceptual sense, inseparably belongs to the perception. The tree simpliciter can burn up, be resolved into its chemical elements, etc. But the sense-the sense of this perception, something belonging necessarily to its essence-cannot burn up; it has no chemical elements, no forces, no real properties" (Ideas I, 216). ${ }^{3}$

The distinction between the physical thing and the noema highlights the importance of distinguishing between the natural and the transcendental point of view. While the tree that grows belongs to the natural world, when it is regarded transcendentally it cannot burn up. Making things and ceasing from existence is only possible for the things in the natural world as well as for people as natural beings. The examination of how the tree is given, i.e., how its sense is constituted does not bring the tree into existence. In general, constitution does not bring things, whether physical or abstract, into existence. It is about the givenness, the sense of things.

\section{3. "Construction" vs constitution}

The difference between the transcendent object of the natural attitude and the examination of its givenness, i.e., the examination of the constitution of its sense is obvious when the focus is on physical objects. However, since mathematics is about abstract objects, its subject matter is ideal, and, in that respect, like the structures that can be found in pure consciousness. For this reason, both mathematics and phenomenology, in Husserl's view are eidetic sciences. Their objects are, in Husserl's terminology,

\footnotetext{
3 “Der Baum schlechthin, das Ding in der Natur, ist nichts weniger als dieses Baumwahrgenommene als solches, das als Wahrnehmungssinn zur jeweiligen Wahrnehmung unabtrennbar gehört. Der Baum schlechthin kann abbrennen, sich in seine chemischen Elemente auflösen usw. Der Sinn aber - Sinn dieser Wahrnehmung, ein notwendig zu ihrem Wesen Gehöriges - kann nicht abbrennen, er hat keine chemischen Elemente, keine Kräfte, keine realien Eigenschaften" (Ideen I, 222).
} 
ideal entities, essences. Husserl's term "essence" aims to capture the necessary, invariant structural features of the phenomena.

Withstanding the similarities between mathematics and phenomenology, or construction and constitution, some of their differences can be brought to light by means of two conceptual distinctions that Husserl establishes in the Ideas I: First, according to Husserl, the ideal essences may be either exact or morphological. In mathematics and physics they are exact. They can be derived deductively from the axioms, but they can also be idealized as ideal 'limits' of the free variation of imagination that cannot be found in sensuous intuition. The essences that pertain to pure consciousness are in turn morphological i.e, essentially inexact essences (Ideas I, §74).

Even more decisive is the distinction between what is transcendent vs. that which is immanent to pure consciousness: To reveal the constitution of any kinds of objects one has to perform the phenomenological reductions. In the reductions, the naïve positing of the existence of nature, sciences and humanities, God, pure logic, and mathematics, as well as the material eidetic disciplines are parenthesized, i.e., interrupted (Ideas I, §59). As explained above, what is bracketed does not disappear but it can be referred to only as parenthesized, as transcendent to the pure consciousness. The pure consciousness is not empty, but it is pure from anything existing in the sense things (whether physical or abstract) exist in the world. The realm of pure consciousness is an eidetic sphere, like the world of mathematics. But whereas the essences examined in phenomenology are immanent, the ones in mathematics are transcendent (note that this is the case even if the mathematics in question is constructivist). The immanent structures clarify the manner of givenness of the transcendent entities. They are the ideal structures used in making sense of the transcendent world. Phenomenology and mathematics thus belong to crucially different dimensions that should not be conflated. This means that the facts from the sciences cannot be used in phenomenological explanations. As Husserl puts it, "not a single theorem, indeed not even an axiom, can be taken and admitted as a premise for phenomenological purposes..." (Ideas I, §61). ${ }^{4}$ Consequently, the phenomenological method is bound to be descriptive as opposed to seeking for nomological explanations. But phenomenology can be, and often is, about mathematics. Then it is a study of the constitution of the concepts of theories and mathematical objects, such as numbers, that are nevertheless transcendent. Phenomenological analyses

\footnotetext{
4 "The only propositions of logic to which phenomenology might ever have occasion to refer would therefore be mere logical axioms, like the law of contradiction, axioms the universal and absolute validity of which it would be able to make evident, however, on the basis of examples included among its own data"(Ideas I, §59).
} 
thus clarify how we constitute the concepts of exact essences (of mathematics). While the constituted concepts are usually morphological, by means of eidetic variation the "ideal" exact concepts, correlated with exact essences, can be constructed in the phenomenological attitude (Ideas I, §74). Thus Husserl hopes to be able to clarify the basic concepts used in the axiomatic theories. In his Formal and Transcendental Logic (1929), Husserl however claims that the mathematicians (but not applied mathematicians) need not to be concerned about how mathematics relates to intuition (FTL, §52). In that work, his constitutive analyses focus on the evidences and the presuppositions used in mathematics.

In Husserl's texts construction is constructing theories, proofs, and concepts in mathematics, in the natural mathematical attitude. When the mathematicians explain how they constructed a particular theorem, they refer to theorems, rules or strategies of proof that were used during the course of the proof. When describing the constitution of something, one describes the presuppositions and the evidences used in the same procedure. The revealed constitutive structures are morphological, essentially inexact, so that they do not admit axiomatization but can only be described. Examples of such structures in Formal and Transcendental Logic are the identity of the ideal objects and the kinds of evidence found in the mathematical construction of a theorem. Moreover, the consciousness as a whole, including the situation in which the judging subject finds herself, will be taken into account in the explanation of the constitution (FTL Appendix II, §2b). Consider, for example, the following description of constitution of a judgment:

"The judgment does not exist only in and during the active constitution, as being livingly generated in this process; rather it becomes the continuously abiding selfsame judgment, as a preserved acquisition dependent on functionings of passivity, these being involved everywhere in the constitution of identically persisting unities, including formations produced actively. So far we have seen only that the acquisition, as an abiding one, is constituted, in the first place, during the living progression of retentional modification, up to the limit where the acquisition is no longer prominent.

Without this sort of preservation in a passive continuous identification, advancing judgmentprocesses - as a living further-forming and connecting of meant categorialia to make the unity of continually new judgments at higher and higher levels - would not be possible. The retentionally subsiding component formations remain, with this modification, within the scope of the judger's unitarily thematizing regard; he can reach back and seize them again, each as having its identical sense; also, in consequence of the new judgment-steps, they can undergo further accretions of sense in new formings" (FTL, Appendix II §3a, 320) ${ }^{5}$

\footnotetext{
5 "das Urteil ist nicht nur in und während der aktiven Konstitution als in ihr lebendig sich erzeugendes, sondern
} wird zum kontinuierlich verbleibenden selben Urteil, als einem sich erhaltenden Erwerb, der eben auch für active 
The active synthesis of a judgment does not take place in isolation but it is dependent on many other acquisitions, such as previously made judgments that are passively held in consciousness. After having been made, the judgments sink into the sedimentations of passivity. But because of the associations "a proposition, a proof, a numerical formation, or the like, can come to mind ... long after the original generating has disappeared; ..." (FTL, Appendix II §3b). For example, one may use a certain theorem in a proof that one has seen used somewhere else. The theorem is then passively given in one's consciousness. It is a part of the sedimentations acquired earlier - the sedimentations that persist in consciousness and that can be brought to mind when needed. Due to sedimentations one has all kinds of expectations and "hunches" about what might work and where:

"When the mathematician, on the basis of the structure and sequence of formulas that he finds in his thinking-situation, anticipates a new theorem and a proof for it with an appropriate style being guided, obviously, by association, which has obscurely awakened earlier similar situations, formulas, and combinations of formulas - , he has not yet found, as he very well knows, any actual cognition, any actual theorems of proof; and that signifies for him, as an analytic mathematician, that he has not yet made those actual judgments and combinations of judgments, in the actual activity of which each thing would spring to the fore from analytic relationships belonging to it originally. That is why he now strives for the explicit action which is his rational activity proper - no matter how necessary the associatively indicative action may remain, as pointing ahead to goals and ways for his rational practice" (FTL, Appendix II, §6, 3278). ${ }^{6}$

In sum, the constitution of the ideal entities becomes visible only in the phenomenological attitude. While the ideal essences may be exact and transcendent, the essential structures revealed by the clarification of their constitution are inexact and can only be described. These essences are immanent to pure consciousness. They are used in the constitution of the concepts of the exact and transcendent essences of mathematics.

Gebilde - wie überall (das ist in jedweder Konstitution identisch verharrender Einheiten) auf Funktionen der Passivität beruht. Soweit wir bisher gekommen sind, ist der Erwerb als bleibender zunächst nur konstitutiert während des lebendigen Fortganges der retentionalen Abwandlung bis zum Limes der Unabgehobenheit. Diese Art der Erhaltung in passiv-kontinuierlicher Identifizierung macht allein fortschreitende Urteilsprozesse als lebendige Fortbildung und Verknüpfung kategorialer Vermeintheiten zur Einheit immer neuer und höherstufiger Urteile möglich" (FTL, 319).

6 "Wenn der M athematiker auf Grund des Baues und der Folge von Formeln, die er in seiner Denksituation vorfindet, nun einen neuen Satz und einen in entsprechendem Stil dafür zu führenden Beweis antizipiert offenbar von der Assoziation, die Frühere Denksituationen, Formeln und Formelverbände dunkel geweckt hat, geleitet - so hat er, wie er wohl wei $\beta$, noch keine wirkliche Erkenntnis, keine wirklichen Sätze und Beweise gefunden, und das besagt für ihn als Analytiker, er hat nicht die wirklichen Urteile und Urteilsverbände aktiv hergestellt, in deren wirklicher Aktivität alles aus original zugehörigen analytischen Verhältnissen hervorspringen würde. Eben darum erstrebt er nun die explizite Aktion, die seine eigentliche Vernunfttätigkeit ist - wie sehr die assoziative indizierende notwendig bleibt, inm Ziel und Wege für seine Vernunftpraxis vorzudeuten" (FTL, 325). 


\section{Logical construction}

Husserl uses the term 'construction' for various kinds of activities. In a wide sense, it refers to any mathematical activity, i.e., any construction of a proof or a theorem in mathematics. Hence, for example, in Prolegomena when explaining the division of labor between mathematicians and philosophers, Husserl writes that "[t]he construction of theories, the strict, methodical solution of all formal problems, will always remain the home domain of the mathematician. " Here Husserl refers to the theories in algebraic approaches but also to Riemann's approach and Cantor's theory of sets ( $\S 70$ 71). In Formal and Transcendental Logic (1929) Husserl writes that mathematics "is the realm of infinite constructions, a realm of ideal existences, not only of 'infinite' senses but also of constructional infinities" (FTL, §74). He thus seems to think that the transfinite sets are constructed. In its wide sense, construction thus refers to any mathematical theorem-proving.

However, in Formal and Transcendental Logic Husserl also uses the term "construction" [Konstruktion] to refer to active judging in accordance to the rules of pure apophantic logic. Husserl writes, that assuming the pure theory of grammar,

"a closed system of fundamental forms emerges, out of which, in accordance with a set of appertinent eidetic laws, ever new, ever more highly differentiated forms, and finally the system of all conceivable judgment-forms without exception, can be generated by construction [konstruktive erzeugt werden können], with the infinity of their differentiated and alwaysfurther-differentiable configurations" (FTL §13b, 50). ${ }^{7}$

From the judgment 'S is p' one can construe the form 'Sp is q' or and then '(Sp)q is r'. These judgments can be 'modified' so that they can occur as component parts in e.g., a conjunction or a hypothetical form of judgments. Such construction is law-governed and reiterative:

"Every operative fashioning of one form out of others has its law; and this law, in the case of operations proper, is of such a nature that the generated form can itself be submitted to a repetition of the same operation. Every law of operation thus bears within itself a law of reiteration. Conformity to this law of reiterable operation extends throughout the whole province of judgments, and makes it possible to construct reiteratively (by means of

\footnotetext{
7 “Um die Idee dieser reinen Formenlehre zu erfassen, hätte man sich klar machen müssen, daß im Absehen auf eine Klassifikation möglicher Urteile überhaupt hinsichtlich ihrer Form 'Grundformen' hervorgehen, bzw. ein geschlossenes System von Grundformen, aus denen vermöge einer eigenen Wesensgesetzlichkeit immer neue, immer reicher differentzierte Formen und schließlich das System aller erdenklichen Urteilsformen überhaupt in der Unendlichkeit ihrer differentzierten und sich immer wieder differenzierenden Gestalten konstruktive erzeugt werden können" (FTL, 55).
} 
fundamental forms and fundamental operations, which can be laid down) the infinity of possible forms of judgments" (FTL §13c, 52-3). ${ }^{8}$

Later on, in the same work, Husserl refers to a theory of judgments as a "transitional link" between the logic of non-contradiction and the truth-logic. In it, construction starts from judging something about an individual object. It starts from the ultimate forms of judgments that feature "ultimate subjects", "ultimate predicates", "ultimate universalities", "ultimate relations" (§82), and it builds iteratively the theory of judgments, first on the level of truths, then analogously on the level of senses. Complex judgments are then effectively reducible to the elementary judgments. ${ }^{9}$ Husserl does not explain why the complex judgments should be reducible to the simple ones, but it seems to be crucial for a theory of judgments to be able to transfer evidence unproblematically from simple judgments of perception to the more complex ones. I will call this more limited notion "logical construction" as opposed to the more general mathematical construction. These different notions of construction show another difference between constitution and construction. Whereas there are several different kinds of construction, the task of revealing the constitution of what is constructed remains the same. Whereas the scope of what can be constructed differs depending on the kind of construction in question, everything, for Husserl, is constituted - not only mathematical objects.

While Husserl is always very clear about the dangers of modeling phenomenology according to mathematics, in Formal and Transcendental Logic he ascribes to logical construction a function that is rather philosophical, even if it is not transcendental phenomenological. For him the theory of judgments is a vehicle that is able to transfer evidence from simple judgments to the complex judgments, and thus to greater parts of mathematics. It thus can be said to give content to at least some of the abstract objects of formal mathematics. Husserl further claims that such "reductive deliberations ... uncover the hidden intentional implications included in judging and in the judgment itself as the product of judging" (FTL §85). Ultimately it

"yields, even for the theory of forms and, subsequently, for procedure in an analytics of consequence-relationships, a principle of genetic order, which at the same time determines the specifically logical aim conferred on analytics with the concepts and laws of truth. With respect

\footnotetext{
8 "jede operative Gestaltung einer Form aus Formen hat ihr Gesetz, und dieses ist bei den eigentlichen Operationen von einer Art, da $\beta$ das Erzeugte abermals derselben Operation unterzogen warden kann. Jedes Operationsgesetz trägt also in sich ein Gesetz der Iteration. Diese Gesetzmäßigkeit iterierbarer Operation geht durch das ganze Urteilsgebiet hindurch und ermöglicht es, mittels aufzustellender Grundformen und Grundoperationen iterative die Undendlichkeit der möglichen Urteilsformen zu konstruieren" (FTL, 57).

${ }^{9}$ Husserl writes that "any actual or possible judgment leads back to ultimate cores when we follow up its syntaxes; accordingly that it is a syntactical structure built ultimately, though perhaps far from immediately, out of elementary cores, which no longer contain any syntaxes" (FTL§82, 202-3).
} 
to the subjective, that signifies that the predelineated order of judgment-forms involves a predelineated order in the process of making materially evident and in the different levels of true materialities themselves" (emphases in the original, FTL, §85). ${ }^{10}$

It shows how the logically constructed region is evident in a manner that ultimately refers to the evidence of the true materialities, i.e., evidence of something perceived. Husserl continues to explain that the theory of judgments thus enables uncovering what he calls the sense-genesis of judgments. Husserl suggests that logical construction, in this strict sense, thus usefully clarifies the generation of senses within the theory of judgments. It thus helps to reveal the constitution of senses. It is thus possible to use formal (i.e., non transcendental) means for clarification of sense genesis. Thus it contributes to a more encompassing project of examining how mathematics in general is constituted.

\section{Why construction, why constitution?}

For Husserl everything that is given - including objects of perception, of imagination, dreams and fiction, values and moral qualities - is constituted. For a philosopher, or a phenomenologist, the task is to uncover the ways in which these different objects and regions are constituted. In phenomenology of mathematics the particularly interesting question concerns the differences between what is constructed in the wide sense as explained above, as opposed to what is logically constructed in the narrow sense. Examining the constitution of these respective regions shows that they differ in the kind of evidence with which they are given. These evidences are ultimately the normative goals for mathematicians or logicians. Mathematicians may strive for different kinds of normative goals, which explains the existence of a plurality of approaches in mathematics: a set theorist strives for a different kind of evidence than a constructivist (for more detail, see Hartimo 2012). The task for phenomenology of mathematics is to examine these different kinds of evidences so that what is genuine can be distinguished from the spurious. The ultimate purpose of giving transcendental constitutive analyses is to clarify the used concepts so that there should be no paradoxes or confusions about senses and evidences. Its task is to describe our consciousness so as to "know thyself", to be clear about our thinking, about what we are doing, what we are striving for, and whether the used concepts are clear enough. The transcendental constitution analysis thus adds to the naively carried out mathematics a kind of metareflection that is

\footnotetext{
10 "Hieraus ergibt sich schon für die Formenlehre und dann für das Vorgehen in einer Analytik der Konsequenz ein Prinzip genetischer Ordnung, die zugleich bestimmend wird für das spezifisch logische Absehen der Analytik, das mit den Wahrheitsbegriffen und Sätzen zum Austrage kommt. In subjektiver Hinsicht besagt das, daß die vorgezeichnete Ordnung der Urteilsformen zugleich in sich birgt eine vorgezeichnete Ordnung sachlicher Evidentmachung und in der Abstufung der wahren Sahlichkeiten selbst" (FTL, 215).
} 
needed for it to be "knowingly" carried out. The intuitionist (in contrast to some constructivists), regarded from the Husserlian point of view, combines this kind of metareflection to his acts of construction without distinguishing between the two points of view. Regarded from this point of view, the intuitionist is not naïve, but restricted to one set of epistemic norms. In contrast, Husserl thinks that this kind of metareflection should likewise be added to the other ways of doing mathematics. The classical mathematicians however are typically naïve "technicians," as Husserl would put it. The advantage of the transcendental point of view is that in it different kinds of attitudes of doing mathematics together with different kinds of epistemic norms determining what is genuine, can and should be distinguished from each other and compared to each other (cf. Ideas II, §49d).

\section{Condusion}

The main difference between constitution and construction is that construction is a mathematical activity, something carried out in natural (mathematical) attitude, while examination of the constitution of the world of mathematics requires the transcendental point of view. In both of its senses, the wide sense that covers all mathematical theorem-proving and the narrow sense (logical construction in theory of judgments), construction has a "narrower" scope than constitution: everything is constituted, but only some of it is or can be constructed. For example, the trees are not constructed, even though we constitute them.

Constitution does not only have a greater scope, but it has more depth too: e.g., clarifying the constitution of a logical construction has to take into account everything in consciousness that relates to the act and the object of construction. The transcendental point of view to construction thus encompasses not only what Husserl calls active syntheses but also passive sedimentations that function in the background of active judging, and in that sense the description of the constitution of a construction makes explicit what is only implicit in construction. Curiously logical construction can be helpful for the more encompassing examination of evidences, and hence for the constitutive study. The role of logical construction (in the strict sense) is to transfer and impart evidence of the simple judgments of perception to logically more complex judgments and ultimately to at least part of mathematics, thus it reveals the sense genesis of the judgment in question. Generally, the study of constitution is important for it clarifies the presuppositions, goals, and concepts of mathematical 
activity, and hence renders it fully understood. Thanks to it, the phenomenologist is able to compare and contrast different kinds of mathematical practices and the evidences related to them.

Van Atten, Mark. (2017). Construction and Constitution in M athematics. In Centrone (ed.). Essays on Husserl's Logic and Philosophy of Mathematics, edited by Stefania Centrone, Synthese Library. Springer. 2017. 265-316.

Da Silva, Jairo José. (2017). Mathematics and Its Applications, A Transcendental-Idealist Perspective, Springer.

Hartimo, M irja (2012). "Husserl's Pluralistic Phenomenology of M athematics". Philosophia M athematica 20(1) 2012. 86-110.

Hartimo, Mirja (2016). Review of M. Van Atten. Essays on Gödel's Reception of Leibniz, Husserl, and Brouwer. Journal for the History and Philosophy of Logic. 2015. DOI 10.1080/01445340.2015.

Hartimo, M irja (2017). Review of Jairo José da Silva. Mathematics and Its Applications, A TranscendentalIdealist Perspective, Springer, 2017. Notre Dame Philosophical Reviews.

Husserl, Edmund. (Ideen I) Ideen zu einer reinen Phänomenologie und phäneomenologischen Philosophie. Erstes Buch. Allgemeine Einführung in die reine Phänomenologie. Herausgegeben von Walter Biemel. Husserliana Band III. Haag: Martinus Nijhoff 1950. English translation: Ideas Pertaining to a Pure Phenomenology and to a Phenomenological Philosophy. First book. General Introduction to a Pure Phenomenology. The Hague, Boston, Lancaster: Martinus Nijhoff. 1983.

Husserl, Edmund (Ideen II) Ideen zur einer reinen Phänomenologie und phänomenologischen Philosophie. Zweites Buch: Phänomenologische Untersuchungen zur Konstitution. Husserliana Band IV. Ed. M. Biemel. The Hague, Netherlands: M artinus Nijhoff, 1952. English translation: Ideas pertaining to a pure phenomenology and to a phenomenological philosophy. Second book, Studies in the Phenomenology of Constitution. Translated by Richard Rojcewicz and André Schuwer. Dordrecht, Boston, London: Kluwer. 1989.

Husserl, Edmund. (Crisis) Die Krisis der europäischen Wissenschaften und die transzendentale Phänomenologie: Eine Einleitung in die phänomenologische Philosophie. Hrsg. W. Biemel. Hua VI. The Hague: Nijhoff, 1954. Reprinted 1976. English translation: The Crisis of the European Sciences and the Transcendental Phenomenology: An Introduction to Phenomenological Philosophy. Trans. David Carr. Evanston: Northwestern University Press, 1970.

Husserl, Edmund. (FTL) Formale und transzendental Logik. Hrsg. Paul Janssen. Hua XVII. Den Haag: M artinus Nijhoff, 1974. English translation: Formal and Transcendental Logic. Trans. D. Cairns. The Hague: Nijhoff, 1969. 